\title{
Democratic Institutions, Natural Resources, and Income Inequality
}

\section{Christopher A. Hartwell ${ }^{a, b}$, Roman Horvath ${ }^{c}$, Eva Horvathova ${ }^{d}$, Olga Popova ${ }^{\text {ef,g }}$}

${ }^{a}$ Bournemouth University, UK. E-mail: chartwell@bournemouth.ac.uk

${ }^{\mathrm{b}}$ Kozminski University, Warsaw, Poland

${ }^{c}$ Charles University, Prague, Czech Republic. E-mail: roman.horvath@fsv.cuni.cz

${ }^{d}$ Global Change Research Institute, Czech Academy of Sciences, Prague, Czech Republic. E-mail: horvathova.e@czechglobe.cz

${ }^{\mathrm{e}}$ Leibniz Institute for East and Southeast European Studies (IOS), Regensburg, Germany. E-mail: popova@ios-regensburg.de

${ }^{f}$ CERGE-El, a joint workplace of Charles University and the Economics Institute of the Czech Academy of Sciences, Prague, Czech Republic

${ }^{\mathrm{g}}$ Graduate School of Economics and Management, Ural Federal University, Yekaterinburg, Russian Federation

Corresponding author: Christopher A. Hartwell, Bournemouth University, UK. Address: Dorset House D129, Dorset House, Talbot Campus, Fern Barrow, Poole, BH12 5BB, UK. E-mail: chartwell@bournemouth.ac.uk

Acknowledgments: We thank Nauro Campos, Jan Mares, and an anonymous referee for helpful comments. Horvathova acknowledges support from the Grant Agency of the Czech Republic, grant no. 17-16633S. Popova acknowledges support from Russian Science Foundation grant no. 19-18-00262.

Published in Comparative Economic Studies, 


\section{Introduction}

While the natural resource curse has been exhaustively examined for its impact on growth (see inter alia Sachs and Warner 2001, Brunnschweiler and Bulte 2008, van der Ploeg 2011, Avalos et al. 2015, and Havranek et al. 2016), the linkages between resource abundance and income inequality are thinner on the ground. Theoretically, the effects of resource abundance on inequality are highly ambiguous. In the first instance, the structure of the economy matters, as capital-intensive resource sectors can draw scarce capital from manufacturing, retarding industrialization and leading directly to widening inequality (Leamer et al. 1999). Along these lines, resource abundance, by fostering dependence on primary exports, can also halt diversified industrialization (i.e. manufacturing not associated with resources) and urbanization, both processes which contribute to lower inequality (Auty 2001).

On the other hand, resource abundance, as a source of wealth for existing generations, may be able to lower inequality in the short- and medium-term. By providing a ready-made industry for a country, one that is labor-intensive, natural resource discoveries may help to raise low-skilled workers out of poverty and flatten a country's income distribution. At the same time, there may be spatial effects resulting from a resource discovery, as urban centers located closer to the discovery can take on the attributes of a "boom town," drawing workers and investors from elsewhere to participate in the bonanza (Eduful and Hooper 2015).

It would appear that the crucial mechanism for transforming resource abundance into lower levels of inequality, allowing for the dispersal of benefits and minimization of costs, would necessarily be a country's institutions, and in particular its political institutions. This reality has been touched upon in many papers examining the political economy of the resource curse: for example, as Parcero and Papyrakis (2016) note, resource abundance can result in lower inequality if the (political) mechanisms 
exist for redistribution of resource rents to broad swathes of society. Similarly, much of the economics and political science literature acknowledges the counterfactual, namely that where these distribution mechanisms are absent - for example if only a small and politically-connected class can reap the benefits of a resource discovery - it is much more likely that inequality will become entrenched or exacerbated. Indeed, it is likely in the interest of ruling elites to keep resource rents concentrated for their own benefit, a strategy which has long-term deleterious effects for the diversification of the economy and, by extension, income inequality (Wiig and Kolstad 2012).

The explicit nature of how specific political institutions mediate resources, and thus affect income inequality, remains an area which has been incorporated into conceptual frameworks only on a peripheral basis. Much like the broader resource curse framework, there has instead been a focus on the effect of political institutions on economic growth in the presence of natural resources (Mehlum et al. 2006), finding either that democracy writ large has little effect on growth in resource-abundant economies (Ross 1999, Kolstad 2009), poor political institutions can encourage rent-seeking and thus retard growth (Atkinson and Hamilton 2003) while good political institutions can prevent such behavior (Brunnschweiler 2008), or that the type of political ordering is crucial in determining the effect of natural resources (Andersen and Aslaksen 2008). Similarly, the literature focusing on the effects of institutions on inequality have tended to avoid incorporating the idea of resource booms, either noting how institutions and inequality influence each other (Chong and Gradstein 2007) or focusing on institutional effectiveness in a broader sense (Chong and Calderon 2000).

This paper, building off of Hartwell (2016) and Hartwell et al. (2019), attempts to survey the current state of the literature regarding the institutions-resources-inequality nexus and offers a way forward for future research and policy. Our working hypothesis is that good political institutions, and in particular 
democraticinstitutions, prevent extreme income polarization in a country blessed with natural resource endowments. Using cross-country data on natural resource rents, levels and changes in political institutions, and the evolution of income inequality, we show that there is no relationship between resource rents and inequality unless one takes into account political institutions. In particular, it appears that democracies tend to minimize resource-related inequality relative to more authoritarian states.

The paper is organized as follows: we present a comprehensive survey of the literature in the following section, while Section 3 provides empirical evidence on the natural resources-inequality-democracy nexus. Concluding remarks, and a challenge for future research, are offered in our final section.

\section{Theory and Literature Review}

As noted above, the theory of linkages between natural resources and income inequality is ambiguous, with little clear-but predictions on how natural resources would impact longer-term trends. Early research into resources and inequality argued that, above all, a country's economic structure matters, in particular its distribution of capital, labor, and productivity. Spilimbergo et al. (1999) typify this line of research, showing that land- and capital- intensive countries have a less equal income distribution, while skill-intensive countries have a more equal income distribution. Leamer et al. (1999) taking this work forward to develop a theory of resource impact on inequality, demonstrate how natural resources can attract scarce capital, resulting in less available investment for manufacturing and other high valueadded sectors required for development. Alvarez and Fuentes (2012) show evidence for this theory, finding that resource-rich countries are less likely to have comparative advantage in manufacturing goods than resource-scarce countries and also are more likely to lose comparative advantage if they attain it. By extension, the growth-impeding effects of resources lead to a lack of development and less ability to flatten the Gini curve. Allcot and Keniston (2018) provide contrary evidence from the US, 
noting that oil and gas booms work to improve local wages without depressing manufacturing, putting these positive effects down to agglomeration. Cavalcanti et al. (2019) also argue that in Brazil, oil discoveries improve local devel opment through urbanization and relocation of workers from agriculture to services. Finally, Goderis and Malone (2011), focusing instead on the labor market side, also show how the presence of a relatively unskilled labor intensive non-traded sector can see a brief decrease in inequality as unskilled workers are drawn into the resource sector, but stagnation and steadily increasing inequality over time as the initial effect of the resource discovery wears off.

Implicit in this work, but rarely explicitly stated, is the role of institutions in affecting both the existing economic structure of a country and in mediating the flows of resources once they are discovered. Indeed, the channels through which resources must run to influence inequality necessarily include the "rules of the game," encapsulated in its institutional make-up, as economicand political institutions can affect utilization and distribution of resources. Hartwell (2016) makes precisely this point in the context of materials use, showing how resource-rich countries tend to use resources in a less efficient manner but effective institutions (above all property rights) can mitigate against waste (Nunez-Rocha and Turcu [2019] also make a similar point regarding the interplay of democracy and effective environmental regulation). With regard to the broader issue of institutions and resource use as related to economic outcomes, Mehlumetal. (2006) make the strongest case for institutional influence, noting that quality institutions help to increase aggregate income up, while poor-quality institutions have the opposite effect. ${ }^{1}$ In line with this finding, Collier and Hoeffler (2009) provide a theoretical framework and show empirically that quality institutions, in particular strong government accountability, enhances economic

\footnotetext{
${ }^{1}$ Boschini et al. (2007) arrive to a similar conclusion and argue that the positive or negative impact of natural resources on economic growth depends not only on institutional quality, but also on the type of natural resources. If institutional quality is good, mineral-rich countries are less likely to suffer from the negative consequences of natural resources as compared to countries rich in diamonds and precious metals.
} 
performance in resource-rich democracies. ${ }^{2}$ Sarmidi et al. (2014) extend this analysis to show that there is a threshold effect in institutional quality, with countries having institutional quality above this threshold contributing to economic growth but countries below it seeing deleterious consequences.

An emerging stream of literature also focuses on the impact of natural resource discoveries on economic outcomes. Existing studies show that oil and minerals discoveries hinder long-run democratic development (Tsui 2011) but enhance long-run economic growth (Smith 2015) and reduce income inequality in developed countries (Hartwell et al. 2019). Bhattacharyya et al. (2017) also suggest that in more democratic countries, oil and minerals discoveries lead to more fiscal autonomy at subnational level, while less democratic countries tend to centralize expenditures.

The literature on the effects of institutions in resource-rich countries al so runs in both directions, finding that not only do institutions affect the way in which resources are utilized but also that, over the longerterm, the presence of resources can also shape institutional evolution. Isham et al. (2005), in a widely cited study, show how point-source resources contribute to poorer governance indicators, even while controlling for export structure, while diffuse source resources do not have the same effect. Mavrotas et al. (2011) formalize these results into a model of rent-seeking contests, also showing that point-source natural resource dependence has a direct effect on institutional development in both governance and democracy (Pomfret [2011] demonstrates this in Central Asia). A substantial body of literature also suggests that natural resources hinder democratic development (Barro 1999, Ross 2001, Aslaksen 2010,

\footnotetext{
${ }^{2}$ Libman (2013) extends this analysis for the case of Russian regions and shows that when institutions are efficient and non-corrupt, natural resource rents may enhance economic growth even in non-democracies. Also, Asiedu and Lien (2011) argue that democracy facilitates FDI in countries where the share of natural resources in total exports is low, but where exports are dominated by natural resource democracy can actually have a negative effect.
} 
Tsui 2011). ${ }^{3}$ However, this does not necessarily lead to poor economic performance, and autocracies with good quality institutions may also have good economic performance (Collier and Hoeffler 2009, Libman 2013, Besley and Kudamatsu 2008). Taking a different approach, Fum and Holder (2010) detail how resources lead to higher stakes in ethnically heterogeneous societies, with ethnic divisions exacerbating inequality in the presence of resource discoveries; as Kyriacou (2013) notes, this is not a surprising result, as fractured societies also have poorer quality institutions.

Of the myriad of institutions which could impact inequality, political institutions have a special role to play, as they should translate the desires of the populace for flatter income distributions into reality via redistributive mechanisms (Meltzer and Richard 1981; Gylfason and Zoega 2003; Islam 2016). In theory, the protection of the poorer members of society would be paramount for a democracy, and thus direct redistribution of resources (via taxation or the provision of public services) could occur (Acemoglu and Robinson 2006; Acemoglu et al. 2019). There need not only be direct redistribution, however, and equality of opportunity and a focus on access to education (Ross 2006) would also result in improved human capital (Rodrik 1999), thus translating into less inequality (Muller 1988, Lake and Baum 2001). This channel could operate even in a country with high social mobility, where the ability to become rich leads most segments of society to favor less redistribution (believing that they themselves will one day be subject to it, see Alesina and La Ferrara 2005). In such an environment, support of access to human capital and preference for equal opportunities would accompany democratization and lead eventually to improved inequality outcomes (Gylfason 2001, Gallego 2010) and higher long-run economic growth

\footnotetext{
${ }^{3}$ In contrast, Haber and Menaldo (2011) suggest that resource rents are not associated with autocracy. Aslaksen and Torvik (2006) also provide a theoretical model and empirical evidence to show that high resource rents combined with low labor productivity increase the likelihood of civil conflict, while high labor productivity makes democracy more likely.
} 
(Acemoglu et al. 2019). ${ }^{4}$ Additionally, democracies facilitate the adoption of economic reforms conducive to growth (Acemoglu et al. 2019, Giuliano et al. 2013), and invest more in capital, schooling, and health (Acemoglu et al. 2019). These dimensions are also complementary to better economic outcomes.

However, the existing evidence of the link between democracy and income inequality writ large is rather inconclusive, with little direct links between the institutions of democracy and lower inequality (see especially Balcazar (2016) in Latin America and Timmons (2010) and Knutsen (2015) for a global look). In some sense, this is related to the distribution of the factors of production pre-democratization, as highly unequal societies before democracy are likely to take a long time to become more equal. Some evidence for this was found by Huber and Stephens (2012) who, examining Latin America, noted that income inequality only began to decline after a period of both economic growth and extended democratization, with the length of time a country remained democratic correlated with lower levels of income inequality; as they conjecture, the longer that a country remains democratic, the more time there is for left-leaning parties to emerge, become legitimized, and enact redistributive policies (eroding traditional elites). ${ }^{5}$ Additionally, Acemoglu and Robinson (2008) also note that informal political institutions can subvert de jure political institutions, and thus the real power distribution within a country could determine inequality and who is allowed to ascend the ladder, i.e. unequal factor distributions could retard the effectiveness of democracy. In this sense, perhaps it is the quality and coverage of democraticinstitutions which matter for inequality rather than their presence (Gupta et al. [2002] note as much by linking high levels of corruption to high income inequality). Caselli and Michaels (2013) also

\footnotetext{
${ }^{4}$ Acemoglu et al. (2019) argue that in the long-run, democratization leads to $20 \%$ increase in GDP per capita. Eberhardt (2019) reassesses this finding and suggests that the impact of democracy is more conservative though still sizeable (about $10 \%)$.

${ }^{5}$ Gerring et al. (2012) also posit that the amount of time under democracy matters for other human development indicators, suggesting that established democracies are better able to handle issues of social protection rather than new ones.
} 
show indirectly that poorer-quality democratic institutions, while channeling funds from resource windfalls to greater spending, also have a gap in the actual flow of goods, services, and transfers to the population versus the reported spending increases accompanying from the windfall. Similarly, Cockx and Francken (2016) show that education spending actually does not increase more in resource-rich countries. To end on a more sanguine note, however, in their examination of transition economies, Gradstein and Milanovic (2004) note that income inequality spiked with democratization, a more welcome outcome (perhaps not for them) in that it resulted from the ability of entrepreneurs to achieve wealth without reliance on the state (Atkinson and Micklewright 1992). ${ }^{6}$

Given that the direct linkages between democracy and inequality are not always clear, it is worthwhile to explore how democracy might mitigate inequality in resource-rich economies. Indeed, we believe that the inclusion of democracy is the final piece of the puzzle in the institutions-resources-inequality nexus: if institutions can mitigate the resource curse and if democracy can have an impact on inequality, then the presence of a democracy in a country which discovers resources can use those resources to mitigate income inequality. In particular, we propose that the influence of democracy would operate through three distinct channels:

1. Executive constraints: Established democracies have a broader number of checks and balances and allow for a larger number of veto players, thus preventing the concentration of political power. With political power more diffuse, there is less likelihood for economic actors to gain political control of resource flows (Bhattacharyya and Hodler 2010) and/or political actors to control resource rents for their own gain (Robinson et al. 2006; Bulte and Damania 2008). Thus,

\footnotetext{
${ }^{6}$ Of course, in some transition countries such as Ukraine and Russia, the drivers of economic inequality were precisely a reliance on the state, as tentative moves towards democracy were accompanied by rent capture by elites. Thus, even the transition experience cannot be generalized into a more/less inequality relationship with democracy.
} 
we would expect to see countries with both democratic political institutions and natural resources to have less inequality than non-democratic regimes (consistent with Goderis and Malone 2011);

2. Equitable sharing: Beyond limiting the power of politicians to aggrandize economic rents, democracies, by voting for social programs, may also tend to spread the resource wealth more than authoritarian regimes (Boix 2003, Ross 2006). In the context of natural resources, democratic countries are better are using the spoils of these endowments to smooth inequalities (Auty 2000). Moreover, the presence of resources makes the act of voting more valuable, thus drawing more actors into the political arena and acting as a check on each other (as a corollary to point 1 above).

3. Utilization of opportunities: Finally, given the diffusion of power which democracy enables and the social spending it encourages, democracy also encourages citizens to maximize their own potential and invest to improve their human capital. In this environment, the presence of natural resources can be a boon (Cabrales and Hauk 2010), providing funding to improve education and thus also increasing income mobility. In contrast to authoritarian regimes, which may also target human capital rents but only narrowly at elites, democracies should enlarge the space of opportunities available at all levels (Saint-Paul and Verdier 1996).

While each of these avenues is theoretically plausible, to our knowledge there is no study which exists that takes into account explicitly the linkages between democracy, resources, and inequality. Our next section attempts to rectify this omission. 


\section{The Evidence}

This section provides new evidence on the natural resources - democracy-inequality nexus. We have collected relevant cross-country data on natural resource rents, income inequality and democracy and have created both visual and econometric evidence for the existence of the relationships amongst these variables.

In the first instance, in order to understand the extent of natural resource abundance in a country, we utilize World Bank data on natural resource rents to gross domestic product (GDP) as a proxy for resource dependence. Total natural resource rents are calculated as the sum of oil rents, natural gas rents, coal rents (hard and soft), mineral rents, and forest rents. The benefit of the natural resource rents ratio is that it has reasonable country and time coverage available annually; to capture long-term trends in resource dependence, we take the average of this variable over 1980 to 2009.

Turning to our inequality data, in order to proxy for inequality in income, we utilize data from Solt (2016). The Standardized World Income Inequality Database (SWIID) is the most comprehensive source on income inequality, and we use the Gini index derived from this database (version 8 ) based on the distribution of pre-taxincome in order to assess the degree of income inequality. ${ }^{7}$ Additionally, we take the average of the Gini coefficient between 2010 and 2016 to eliminate potential one-off shocks.

\footnotetext{
${ }^{7}$ The issue of income inequality data comparability and coverage has been extensively discussed in the literature (Atkinson and Brandolini 2001 and 2009, Jenkins 2015, Solt 2016). Earlier versions of the SWIID database have also been criticized for imperfect imputation of missing data (Jenkins 2015). However, as detailed in Solt (2015) and (2016), starting from the version 5.0 (October 2014), the SWIID data took into account the earlier critiques and were substantially updated. A comprehensive documentation regarding the SWIID methodology is provided in Solt (2016). To date, the SWIID database remains the most comprehensive source on income inequality data comparable across countries (Solt 2016).
} 
Finally, we use the democratic accountability score from the International Country Risk Guide (ICRG) dataset, originally scaled from 0 to 6 with higher numbers signaling higher levels of representation and checks and balances but re-scaled in our database from 0 to 1 for ease of interpretation. There are more databases providing an assessment of the degree of democracy in a given country, but the ICRG database has the most extensive coverage (and democracy scores from different databases are typically highly correlated as well). A drawback of the ICRG democracy indicator is that it does not allow us specifically to disentangle the channels via which democracy may be influencing inequality (as shown above), in that it focuses on the broaderidea of democratic accountability, i.e. the responsiveness of a government to its citizens. While this should encompass the theoretical links noted above, it is possible that it misses some of the other channels through which democracy may operate, including expenditures on human capital and/or health. Nonetheless, we feel that this indicator is most appropriate for gauging the level of democracy within a country.

To examine the differential effect of natural resources on income inequality, we distinguish in our sample among the least and the most democratic countries. We assume that the least democratic countries in our global sample are those with the democratic accountability score below the $25 \%$ percentile. Similarly, we consider the most democratic countries as those with the score above the $75 \%$ percentile. ${ }^{8}$ Alternatively, we also use the measure of institutional quality (computed as the average of three constituent indicators, namely corruption, bureaucratic quality, and law and order) from the International Country Risk Guide dataset and find that our results presented below are robust to replacing democratic accountability with institutional quality. This result is not so surprising given that the correlation between democratic accountability and institutional quality is 0.81 in our sample (and

\footnotetext{
${ }^{8}$ We areaware that these cut-off points are somewhat arbitrary, but further robustness tests conducted after our examination show that the results are unaffected even if we change the cut-off points upwards or downwards.
} 
theoretically, there are many overlaps between an institutional matrix which is accountable to veto players and one which is perceived to be less corrupt and have more respect for rule of law).

\section{Natural Resources and Income Inequality}

The first evidence we have of the relationships between natural resources and income inequality is, as noted above, presented graphically in Figure 1, a scatter plot based on observations from 122 countries. Contrary to previous literature, we find that the link between natural resources and income inequality is essentially zero in ourglobal sample (a fact also confirmed by the correlation coefficient of -0.02). It is important to note that our examination uses the lags of natural resources rents, based on the period 1980-2009, done so to reduce endogeneity concerns, while income inequality is based on more recent data (the average taken over 2010-2016); however, given that the effects of resources on income should not be contemporaneous, the lack of any relationship in this examination seems definitive.

This relationship appears to change when we introduce the issue of institutional efficacy, namely democracy, into the picture. Indeed, examining the link between natural resources and income inequality for the most and least democratic countries (Figure 2), we observe that a systematic pattern between resources and inequality emerges. The left part of Figure 2 shows the scatter plot for the least democratic countries, while the right part shows it for the most democratic countries. We observe that income inequality appears to be, on average, higher in resource-rich countries when the level of democracy in the countries in our set is low (an example of such countries includes Angola, Congo, and Sudan), with a corresponding correlation coefficient of 0.16 . On the other hand, democratic countries such as Australia, Canada, or Norway exhibit a lower degree of income inequality where they have abundant natural resources, as shown in the second panel of Figure 2, with a corresponding correlation 
coefficient of -0.12 . These results suggest that democratic countries redistribute the part of natural resource revenues to the society, exactly as the theory predicts.

Figure 1-Natural Resource Rents and Income Inequality: All Countries

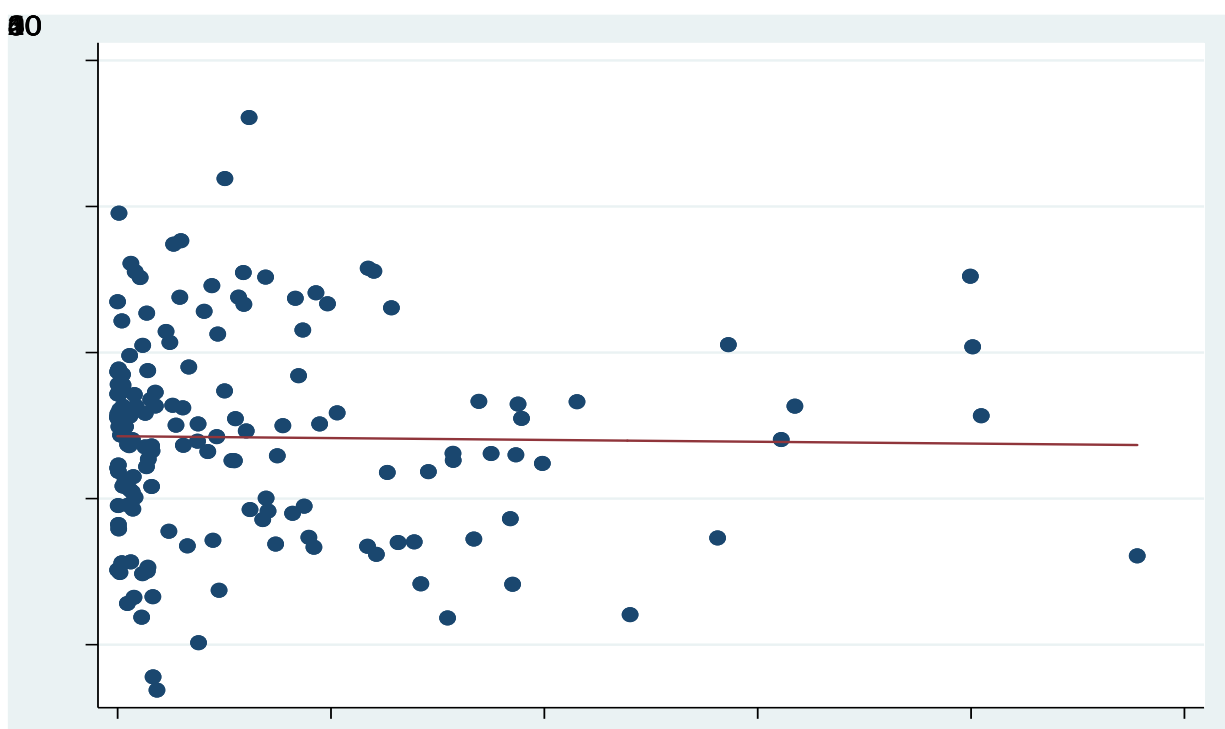

Note: Natural resource rents to GDP - World Bank Dataset. Total natural resource rents are the sum of oil rents, natural gas rents, coal rents (hard and soft), mineral rents, and forest rents. Average 1980-2009. Income Inequality - Gini index based on the distribution of pre-tax income (The Standardized World Income Inequality Database), average 2010-2016, Solt (2016).

Figure 2- Natural Resource Rents and Income Inequality: Democracy Matters

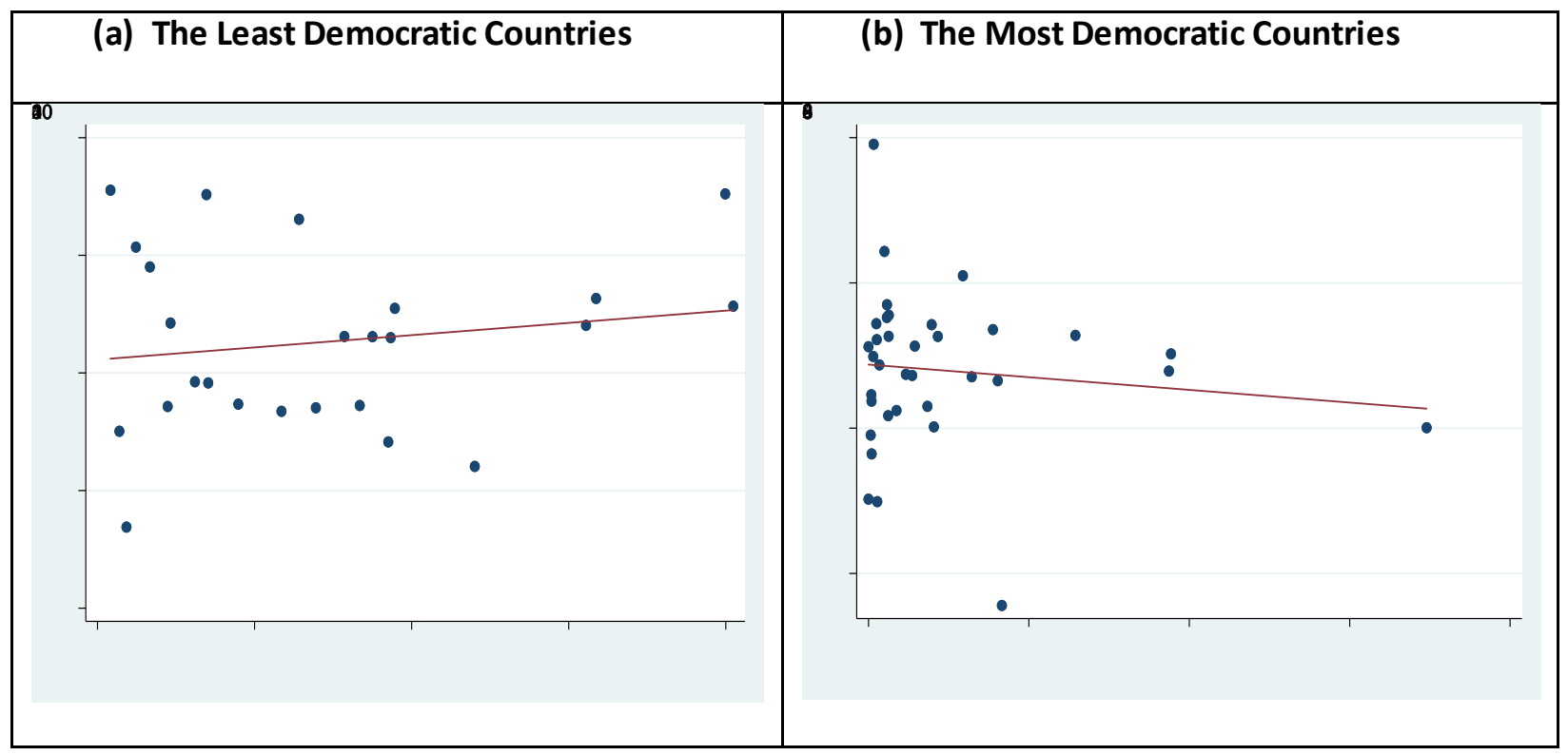


Note: Rents and income inequality as above. The least democratic countries defined as those with the democratic accountability score from ICRG dataset below the 25th percentile. The most democratic countries defined as those with the democratic accountability score from ICRG dataset above the 75th percentile.

\section{Natural Resources, Democracy and Inequality: Regression Analysis}

This analysis, while providing some evidence for the impact of democracy on the natural resourcesinequality nexus, is based mainly on correlations. In order to complement this evidence on the effect in a more rigorous manner, we use a reduced-form model to further tease out the effects of democracy. We use a cross-sectional global dataset as noted above, regressing income inequality on a series of lagged explanatory variables (the explanatory variables are lagged again to, in principle, address potential concerns about endogeneity). We estimate the following equation using ordinary least squares (OLS):

$$
\text { Inclneq }_{j}=a_{0}+a_{1}{ }^{*} \text { NatRes }_{j}+a_{2}{ }^{*} \text { NatRes }_{j}^{*} \text { Democr }_{j}+a_{i}{ }^{*} X_{j}+e_{j}
$$

Where Inclneq represents the measure of income inequality in country $j$, NatRes captures the natural resource rents, Democr denotes the level of democratic accountability, $X$ is a matrix of control variables, and $e$ represents the error term. The data definitions and the sources are available in Table A.1 in the Appendix, while descriptive statistics are available in Table A.2.

We motivate the specification of our regression model by previous evidence on the cross-country determinants of income inequality. Importantly, we include the level of generalized trust, as Uslaner (2009) extensively showed that trust is strongly linked to inequality. Additionally, we control for several variables capturing the level of economic development, education, financial development, demography, labor market flexibility, technological progress, and political stability. This choice can be rationalized by previous research on the determinants of income inequality (Roine et al. [2009] and Tridico [2018] and 
references therein). For example, Claessens and Perotti (2007) also provide a survey of how financial development can affect income inequality and show that it can both increase or decrease inequality depending on the characteristics of financial development. Along theselines, Pastor and Veronesi (2016) develop a theoretical model of asset price formation, which, among other results, implies that skill heterogeneity (which is often linked to technological progress) causes inequality. Similar arguments on how technological progress affects the skill premium and subsequently income inequality are also raised by Dabla-Norris et al. (2015) and Milanovic(2016). Bircan et al. (2017) show how political instability and conflicts translate into greater income inequality, while Tridico (2018) finds that greater labor market flexibility has been associated with greater inequality in the OECD countries. Scheidel (2017) argues that the effects of education on inequality are not clear-cut; on the one hand, education can lower the gap between rich and poor but on the other hand, elite school systems and assortative mating may propagate inequality across generations.

Table 1 - What Determines Income Inequality? Regression Analysis

\begin{tabular}{lrlllll}
\hline \hline & \multicolumn{1}{c}{$(1)$} & \multicolumn{1}{c}{$(2)$} & \multicolumn{1}{c}{$(3)$} & \multicolumn{1}{c}{$(4)$} & \multicolumn{1}{c}{$(5)$} & \multicolumn{1}{c}{$(6)$} \\
\hline Natural resource & $0.55^{*}$ & $0.53^{*}$ & $0.54^{* *}$ & $0.51^{*}$ & $0.61^{* *}$ & $0.55^{*}$ \\
& $(0.28)$ & $(0.27)$ & $(0.27)$ & $(0.26)$ & $(0.28)$ & $(0.32)$ \\
Nat. Res. *Democracy & $-1.53^{* *}$ & $-1.61^{* *}$ & $-1.58^{* *}$ & $-1.53^{* *}$ & $-1.73^{* *}$ & $-1.57^{* *}$ \\
& $(0.64)$ & $(0.64)$ & $(0.63)$ & $(0.61)$ & $(0.67)$ & $(0.71)$ \\
Trust & $-8.99^{* *}$ & $-6.81^{*}$ & $-8.18^{*}$ & -7.96 & -7.73 & $-10.00^{*}$ \\
& $(4.18)$ & $(4.28)$ & $(4.97)$ & $(5.19)$ & $(5.41)$ & $(5.85)$ \\
Education expenditures & $0.70^{*}$ & $0.77^{*}$ & $0.65^{*}$ & $0.65^{* *}$ & $0.66^{* *}$ & $0.70^{* *}$ \\
& $(0.32)$ & $(0.31)$ & $(0.34)$ & $(0.29)$ & $(0.29)$ & $(0.32)$ \\
Revolutions and coups & $0.49^{* *}$ & $0.48^{* *}$ & $0.50^{* *}$ & $0.52^{* *}$ & $0.56^{* *}$ & $0.59^{* *}$ \\
& $(0.21)$ & $(0.20)$ & $(0.22)$ & $(0.23)$ & $(0.22)$ & $(0.23)$ \\
Life expectancy & & -0.11 & -0.23 & -0.22 & -0.25 & -0.32 \\
& & $(0.11)$ & $(0.24)$ & $(0.23)$ & $(0.24)$ & $(0.27)$ \\
Technological progress & & & 2.08 & 2.02 & -0.92 & -0.46 \\
& & & $(2.84)$ & $(2.72)$ & $(4.19)$ & $(4.30)$ \\
Labor market regulations & & & & -2.11 & -1.99 & -1.86 \\
& & & & $(1.31)$ & $(1.33)$ & $(1.29)$ \\
GDP p.c. & & & & & 2.32 & 2.39 \\
& & & & & $(1.99)$ & $(1.99)$ \\
Net interest margin & & & & & & -0.29 \\
\hline \hline
\end{tabular}




\begin{tabular}{lllllll}
\hline \hline & & & & & & $(0.42)$ \\
\hline R-squared & 0.19 & 0.20 & 0.21 & 0.24 & 0.25 & 0.26 \\
No. of observations & 78 & 78 & 76 & 76 & 75 & 75 \\
\hline
\end{tabular}

Note: $\overline{\overline{R o b u s t} \text { standard errors. }{ }^{*}, * * * *}$ - denotes statistical significance at the $10 \%, 5 \%$ and $1 \%$ level respectively. Constant not reported.

Our regression results are available in Table 1 . We find that higher natural resource rents are indeed associated with greater income inequality unless the level of democracy is high, and for democratic countries, we find the opposite effect, i.e. natural resources are associated with less inequality. This result confirms the graphic/correlation analysis of the previous subsection and also is in line with our theoretical supposition that natural resource curse (in terms of high inequality) is not inevitable. ${ }^{9}$

Several control variables are statistically significant as well, with their effects largely in line with the studies mentioned in the previous paragraph. We find that generalized trust lowers inequality, but education expenditures and political instability tend to increase inequality. Greater labor market regulations tend to decrease inequality, but this effect is not statistically significant in our sample. Similarly, we fail to find that technological progress, life expectancy, financial development, and level of economic development as the drivers of income inequality in our sample. Further research may examine to what extent these results hold, if we use different proxies for these factors.

\section{Natural resource discoveries and income inequality in three European democracies}

As a final attempt to shed light on the relationship between natural resources, income inequality, and political institutions, we utilize the synthetic control method by Abadie et al. (2010) to assess the

\footnotetext{
${ }^{9}$ According to our results, an average level of democracy with an average level of natural resource abundance reduces inequality. Within the average level of natural resource abundance, the turning point for democracy vis $a$ vis inequality is a score of 0.36 , which is, for example, Uganda or Vietnam in our sample. Thus, our results suggest that countries with a democracy score above 0.36 will be better situated to utilize natural resource discoveries to lower income inequality. However, given that this is a first attempt at exploring this relationship, we do not want to overemphasize the precision of the estimated coefficients and are more interested in the average effects.
} 
consequences of a natural resource shock (i.e. a resource discovery) on income inequality. The synthetic control method builds on the difference-in-differences estimator and allows a researcher to calculate the counterfactual of what income inequality would be if natural resources had not been discovered (hence the usage of a resource discovery rather than reliance on resources); the actual level of income inequality can then be compared to its counterfactual values and the shock interpreted as a causal mechanism.

In this section, we focus on three highly developed European countries with well-functioning democratic institutions (in this case, Denmark, the Netherlands, and Norway) rather than countries across the political spectrum. This choice is motivated by two points, one theoretical and one practical. Theoretically, using high-functioning democracies allows us to assess further whether natural resources can help to reduce inequality in democratic societies via the channels noted above. At a practical level, data availability is also somewhat restricted, as natural resource discoveries concentrate in the 1960s1980s, which is also the period for which the reliable income inequality data are typically available only for high-income countries. The data availability issues also dictate that we use the $1 \%$ and $10 \%$ income share as the measure of income inequality rather that the Gini coefficient.

The long-run evolution of the $1 \%$ - and $10 \%$-income shares in the three analyzed countries also has a number of similarities. First, all three countries present a successful example of combining wellfunctioning institutions with declining income inequality (Aaberge and Atkinson 2010; Atkinson and Søgaard 2016; de Meere 1983; Soltow and van Zanden 1998; Van Bavel and Frankema 2017). Also, all three countries experienced declining income inequality, as measured by top $1 \%$ and top $10 \%$ income shares, over a similar time-frame, namely after industrialization in the end of $19^{\text {th }}$ and beginning of the $20^{\text {th }}$ century, post-World War II, and in the last decades of the $20^{\text {th }}$ century (see Atkinson and Søgaard 
2016 on trends in Denmark, Aaberge and Atkinson 2010 on trends in Norway, and de Meere 1983; Soltow and van Zanden 1998; and Van Bavel and Frankema 2017 for the Netherlands). In line with Piketty et al. (2014) and Alvaredo et al. (2013), Atkinson and Søgaard (2016) note that such long-run trends do not merely reflect labor market responses to redistributive policies developments in those countries.

The econometric method, data, timing of natural resources discoveries, and individual country results are described in detail in Hartwell et al. (2019). In this article, we follow Cavallo et al. (2013) and present the average effect of natural resource discoveries on income inequality, where the average is taken across our three countries. For each country, we normalize the year of natural resource discovery as year zero and the level of income inequality in the year of natural resource discovery to the level of one.

Figure 3- Natural Resource Discoveries and Top 1\% Share Income Inequality: Actual vs. Counterfactual 


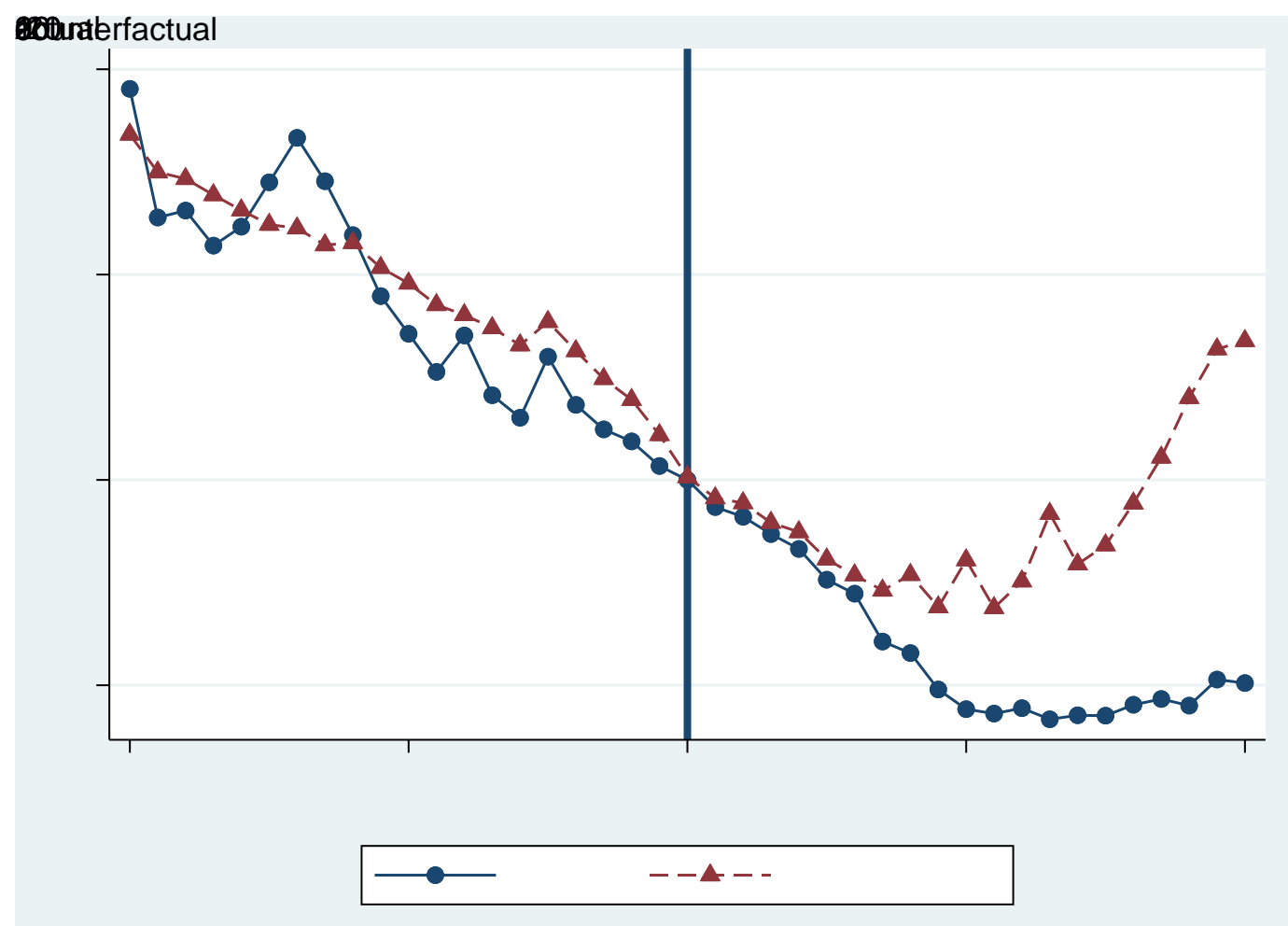

Note: Actual and counterfactual path of income inequality 20 years before and after the natural resource discovery. Path shown is the average across Denmark, the Netherlands, and Norway. The income inequality measure is normalized to 1 in the year 0 (i.e. the year of natural resource discovery).

We present the results for the top $1 \%$ income share in Figure 3, shown as the evolution of income inequality both 20 years before and after the natural resource discovery. We find that the synthetic income inequality (labelled in Figure 3 as the counterfactual) is approximately $10-25 \%$ higher than its actual counterpart. The results further support our baseline findings that natural resources need not translate into greater inequality in democratic societies. According to our results (and as Hartwell et al. (2019) suggest), natural resource discoveries in these countries causally affected income inequality dynamics. We observe similar results for the top $10 \%$ income share (Figure 4). While counterfactual inequality stagnates or increases somewhat, actual income inequality falls following the natural resource discovery.

Figure 4-Natural Resource Discoveries and Top 10\% Share Income Inequality: 


\section{Actual vs. Counterfactual}

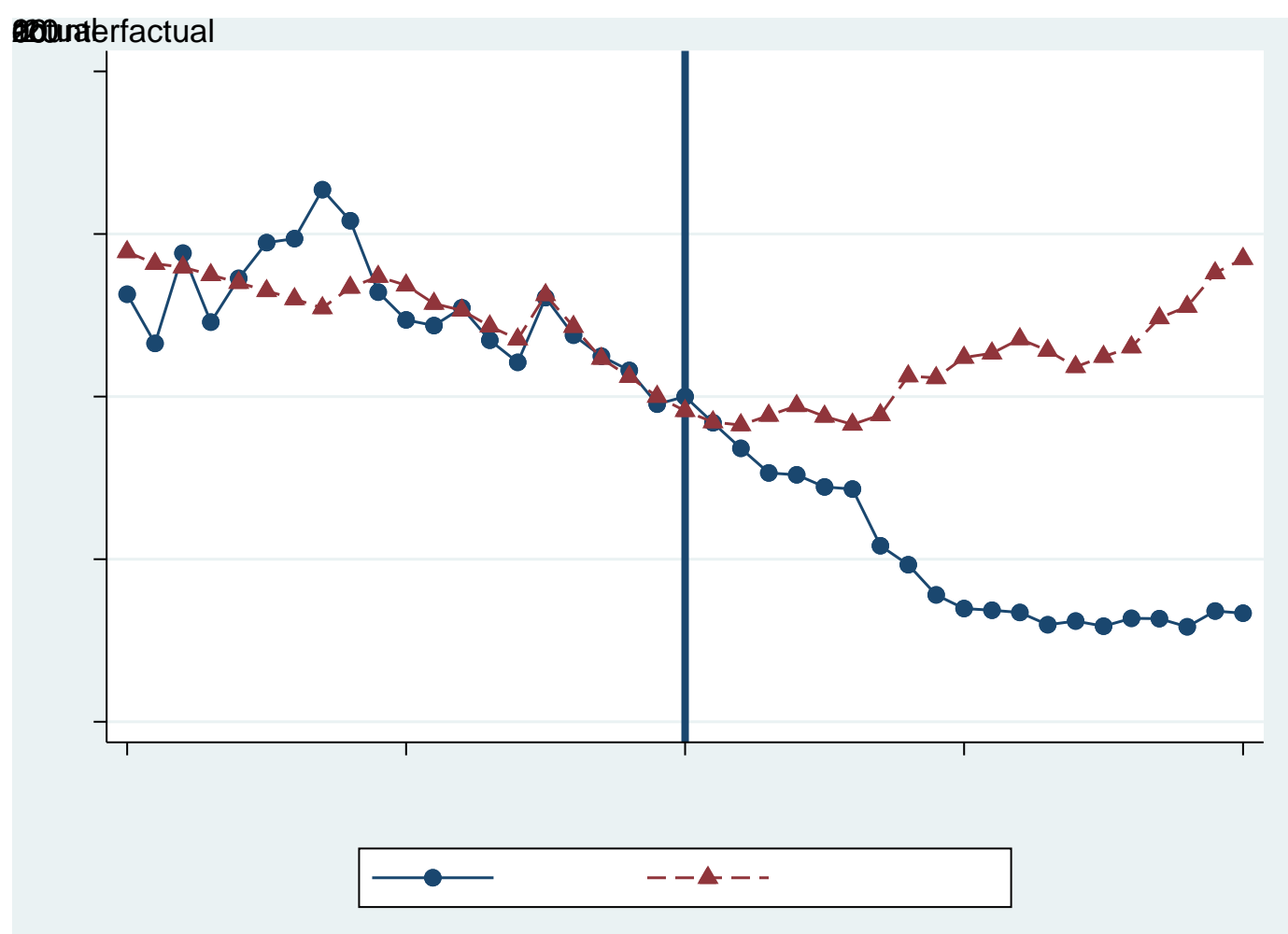

Note: Actual and counterfactual path of income inequality 20 years before and after the natural resource discovery. Path shown is the average across Denmark, the Netherlands, and Norway. The income inequality measure is normalized to 1 in the year 0 (i.e. the year of natural resource discovery).

\section{Concluding Remarks}

Far from being the definitive word in the relationship between political institutions and natural resources, this paper is instead intended as an opening salvo, a survey of the existing landscape on this nexus and a way to spark more research and debate. In particular, we provide a survey of the literature and theory on how political institutions would interact with natural resources and income inequality, complementing this survey with empirical evidence showing the non-linear effect of natural resources on income inequality. As a result of this examination, we find that natural resources increase income inequality only in non-democratic countries, while democratic institutions appear to be effective at preventing inequality. Combined with earlier work done by the authors on the effects of natural 
resource discoveries via the synthetic control method, we also show how the actual evolution of the path of inequality in highly-devel oped democracies is significantly lower after a resource discovery than would be predicted by the synthetic counterfactual.

Given that this is merely a first attempt to examine the link between democracy and inequality in the face of resources, in terms of future research, the possibilities are very open indeed. In the first instance, more rigorous modelling, extended further back than the data currently allows, would be welcome, especially if the modelling could be matched to a formal model of the interplay between resources, democracy, and inequality. Secondly, utilization of various metrics of income inequality, and especially a comparison of these metrics in relation to institutional features, would be a valid extension of this work: do some metrics of inequality show different effects in the presence of democracy and resources? Or are all metrics showing the same effect?

Along these lines, democracies are not all created equal, and exciting research has been done in recent years in exploring the "varieties of democracy," encapsulated in the V-Dem project at the Department of Political Science at the University of Gothenburg. ${ }^{10}$ While we use aggregated indices for democracy in this paper, perhaps breaking out the various varieties of democracy would yield more useful insights in understanding how democracy mediates against inequal ity and the resources curse. Similarly, perhaps a more precise delineation of democratic processes, such as those found in the Max Range dataset on political institutions (Rånge and Sandberg 2017), could also help us to understand the exact channels via which political regimes influence inequality. As an extension of the work we do here, it also could be important to more precisely pinpoint the level of democracy at which natural resource discoveries

\footnotetext{
${ }^{10}$ See their website at https://www.v-dem.net/en/.
} 
become beneficial for alleviating income inequality (or which facet of democracy needs to develop the most for this to occur).

We also believe it would be worthwhile to explore not only the effect of natural resources on income inequality but also on wealth inequality. Unfortunately, the limited data on wealth inequality makes it difficult at the moment to conduct a broad panel data analysis, but researchers should take up this challenge to also attempt to fashion excellent metrics of weal th inequality with both good coverage and a longer time-series. Moreover, the determinants of wealth inequality are largely unexplored, and natural resources may be one of contributing factors driving wealth inequality, especially in resourcerich countries. Will the effects of natural resources on wealth inequality be identical to the effects on income inequality? Will democratic institutions shape the links between natural resources and wealth inequality?

As noted, the possibilities are wide open for continuing to explore these relationships, and we hope that other researchers will take up this challenge in the years to come.

\section{REFERENCES}

Aaberge, R., \& Atkinson, A.B. (2010). Top incomes in Norway. In: Atkinson, A.B., \& Piketty, T. (eds.) Top Incomes: Global Perspective, 448-481, Oxford: Oxford University Press.

Abadie, A., A. Diamond, \& J. Hainmueller (2010). Synthetic control methods for comparative case studies: Estimating the effect of California tobacco control program. Journal of the American Statistical Association 105 (490), 493-505. 
Acemoglu, D., Naidu, S., Restrepo, P., \& J.A. Robinson (2019). Democracy does cause growth. Journal of Political Economy, 127(1), 47-100.

Acemoglu, D., \& Robinson, J. A. (2006). The Economic Origins of Dictatorship and Democracy. Cambridge: Cambridge University Press.

Acemoglu, D., \& Robinson, J. A. (2008). Persistence of power, elites, and institutions. American Economic Review, 98(1), 267-93.

Alesina, A., \& La Ferrara, E. (2005). Preferences for redistribution in the land of opportunities. Journal of Public Economics, 89(5-6), 897-931.

Allcott, H., \& Keniston, D. (2017). Dutch disease or agglomeration? The local economic effects of natural resource booms in modern America. The Review of Economic Studies, 85(2), 695-731.

Alvaredo, F., Atkinson, A. B., Piketty, T., \& Saez, E. (2013). The top 1 percent in international and historical perspective. Journal of Economic Perspectives, 27, 3-20.

Álvarez, R., \& Fuentes, J. R. (2012). Specialization dynamics and natural resources abundance. Review of World Economics, 148(4), 733-750.

Andersen, J. J., \& Aslaksen, S. (2008). Constitutions and the resource curse. Journal of Development Economics, 87(2), 227-246.

Asiedu, E., \& Lien, D. (2011). Democracy, foreign direct investment and natural resources. Journal of International Economics, 84(1), 99-111. 
Aslaksen, S. (2010). Oil and democracy: More than a cross-country correlation? Journal of Peace Research, 47(4), 421-431.

Aslaksen, S., \& Torvik, R. (2006). A theory of civil conflict and democracy in rentier states. Scandinavian Journal of Economics, 108(4), 571-585.

Atkinson, A.B., \& Brandolini, A. (2009). On data: A case study of the evolution of income inequality across time and across countries. Cambridge Journal of Economics, 33, 381-404.

Atkinson, A.B., \& Brandolini, A. (2001). Promise and pitfalls in the use of "secondary" datasets: Income inequality in OECD countries as a case study. Journal of Economic Literature, 39(3), 771-799.

Atkinson, A. B., \& Micklewright, J. (1992). Economic transformation in Eastern Europe and the distribution of income. Cambridge: Cambridge University Press.

Atkinson, A. B., \& Søgaard, J. E. (2016). The long-run history of income inequality in Denmark. The Scandinavian Journal of Economics, 118(2), 264-291.

Atkinson, G., \& Hamilton, K. (2003). Savings, growth and the resource curse hypothesis. World Development, 31(11), 1793-1807.

Auty, R. M. (2000). How natural resources affect economic development. Development Policy Review, 18(4), 347-364.

Auty, R. M. (2001). The political economy of resource-driven growth. European Economic Review, 45(46), 839-846. 
Avalos, N., Stuva, V. G., Heal, A., Lida, K., \& Okazoe, N. (2015). Papua New Guinea and the natural resource curse. Comparative Economic Studies, 57(2), 345-360.

Balcázar, C. F. (2016). Long-run effects of democracy on income inequality in Latin America. The Journal of Economic Inequality, 14(3), 289-307.

Barro, R. J. (1999). Determinants of democracy. Journal of Political Economy, 107(S6), S158-S183.

Besley, T., \& Kudamatsu, M. (2008). Making autocracy work. In: Helpman, E. (ed.), Institutions and Economic Performance, 452-510, Cambridge MA: Harvard University Press.

Bhattacharyya, S., \& Conradie, L., \& Arezki, R. (2017). Resource discovery and the politics of fiscal decentralization. Journal of Comparative Economics, 45, 366-382.

Bhattacharyya, S., \& Hodler, R. (2010). Natural resources, democracy and corruption. European Economic Review, 54(4), 608-621.

Bircan, C., \& Brück, T. \& Vothknecht, M. (2017). Violent conflict and inequality. Oxford Development Studies, 45(2), 125-144.

Boix, C. (2003). Democracy and Redistribution. Cambridge: Cambridge University Press.

Boschini, A.D., \&, Pettersson, J., \& Roine, J. (2007). Resource curse or not: A question of appropriability. Scandinavian Journal of Economics, 109(3), 593-617.

Brunnschweiler, C. N. (2008). Cursing the blessings? Natural resource abundance, institutions, and economic growth. World Development, 36(3), 399-419. 
Brunnschweiler, C. N., \& Bulte, E. H. (2008). The resource curse revisited and revised: A tale of paradoxes and red herrings. Journal of environmental economics and management, 55(3), 248-264.

Bulte, E., \& Damania, R. (2008). Resources for sale: Corruption, democracy and the natural resource curse. The BE Journal of Economic Analysis \& Policy, 8(1).

Cabrales, A., \& Hauk, E. (2011). The quality of political institutions and the curse of natural resources. The Economic Journal, 121(551), 58-88.

Campos, N. \& Nugent, J. (2012). The dynamics of the regulation of labor in developing and developed Countries since 1960. IZA DP No. 6881.

Caselli, F., \& Michaels, G. (2013). Do oil windfalls improve living standards? Evidence from Brazil. American Economic Journal: Applied Economics, 5(1), 208-38.

Cavalcanti, T., \& Da Mata, D., \& Toscani, F. (2019). Winning the oil lottery: The impact of natural resource extraction on growth. Journal of Economic Growth, 24(1), 79-115.

Cavallo, E., S. Galiani, I. Noy, and J. Pantano (2013). Catastrophic natural disasters and economic growth. Review of Economics and Statistics 95 (5), 1549-1561.

Chong, A., \& Calderon, C. (2000). Institutional quality and income distribution. Economic Development and Cultural Change, 48(4), 761-786.

Chong, A., \& Gradstein, M. (2007). Inequality and institutions. The Review of Economics and Statistics, 89(3), 454-465. 
Claessens, S., \& Perotti, E. (2007). Finance and inequality: Channels and evidence. Journal of Comparative Economics, 35(4), 748-773.

Cockx, L., \& Francken, N. (2016). Natural resources: A curse on education spending? Energy Policy, 92, 394-408.

Comin, D.A., \& Hobijn, B. (2009). The CHAT Dataset. NBER WP. No. 15319.

Dabla-Norris, E., K. Kochhar, N. Suphaphiphat, F. Ricka, and E. Tsounta (2015). Causes and consequences of income inequality: A global perspective. International Monetary Fund Discussion Note, SDN/15/13.

De Meere, J.M.M. (1983). Long-term trends in income and wealth inequality in the Netherlands 18081940. Historical Social Research, 27, 8-37.

Eberhardt, M. (2019). Democracy does cause growth: Comment. CEPR Discussion Paper 13659.

Eduful, A., \& Hooper, M. (2015). Urban impacts of resource booms: The emergence of oil-led gentrification in Sekondi-Takoradi, Ghana. Urban Forum, 26(3), 283-302.

Fum, R. M., \& Hodler, R. (2010). Natural resources and income inequality: The role of ethnic divisions. Economics Letters, 107(3), 360-363.

Gallego, F. A. (2010). Historical origins of schooling: The role of democracy and political decentralization. The Review of Economics and Statistics, 92(2), 228-243.

Gerring, J., Thacker, S. C., \& Alfaro, R. (2012). Democracy and human development. The Journal of Politics, 74(1), 1-17. 
Giuliano, P., Mishra, P., \& A. Spilimbergo (2019). Democracy and reforms: Evidence from a new dataset. American Economic Journal: Macroeconomics, 5(4), 179-204.

Goderis, B., \& Malone, S. W. (2011). Natural resource booms and inequality: Theory and evidence. Scandinavian Journal of Economics, 113(2), 388-417.

Gradstein, M., \& Milanovic, B. (2004). Does liberté= égalité? A survey of the empirical links between democracy and inequality with some evidence on the transition economies. Journal of Economic Surveys, 18(4), 515-537.

Gupta, S., Davoodi, H., \& Alonso-Terme, R. (2002). Does corruption affect income inequality and poverty? Economics of Governance, 3(1), 23-45.

Gylfason, T. (2001). Natural resources, education, and economic development. European Economic Review, 45(4-6), 847-859.

Gylfason, T., \& Zoega, G. (2003). Inequality and economic growth: Do natural resources matter? In Eicher, T.S., \& Turnovsky, S.J. (eds.), Inequality and Growth: Theory and Policy Implications. Cambridge, MA: MIT Press, pp. 255-292.

Haber, S., \& Menaldo, V. (2011). Do natural resources fuel authoritarianism? A reappraisal of the resource curse. American Political Science Review, 105(1), 1-26.

Havranek, T. \& Horvath, R. \& Zeynalov, A. (2016). Natural resources and economic growth: A metaanalysis. World Development, 88(C), 134-151.

Hartwell, C. A. (2016). The institutional basis of efficiency in resource-rich countries. Economic Systems, 40(4), 519-538. 
Hartwell, C. A., \& Horvath, R., \& Horvathova, E., \& Popova, O. (2019). Natural Resources and Income Inequality in Developed Countries: Synthetic Control Method Evidence. IOS working paper 381.

Huber, E., \& Stephens, J. (2012). Democracy and the left: Social policy and inequality in Latin America. Chicago: University of Chicago Press.

Isham, J., Woolcock, M., Pritchett, L., \& Busby, G. (2005). The varieties of resource experience: natural resource export structures and the political economy of economic growth. The World Bank Economic Review, 19(2), 141-174.

Islam, M. N. (2016). Does democracy reduce income inequality? Empirical Economics, 51(4), 1299-1318.

Jenkins, S.P. (2015). World income inequality databases: An assessment of WIID and SWIID. Journal of Economic Inequality, 13, 629-671.

Kolstad, I. (2009). The resource curse: Which institutions matter? Applied Economics Letters, 16(4), 439442.

Knutsen, C. H. (2015). Reinvestigating the reciprocal relationship between democracy and income inequality. Review of Economics and Institutions, 6(2), 37.

Kyriacou, A. P. (2013). Ethnic group inequalities and governance: Evidence from developing countries. Kyklos, 66(1), 78-101.

Lake, D. A., \& Baum, M. A. (2001). The invisible hand of democracy: Political control and the provision of public services. Comparative Political Studies, 34(6), 587-621. 
Leamer, E. E., Maul, H., Rodriguez, S., \& Schott, P. K. (1999). Does natural resource abundance increase Latin American income inequality? Journal of Development Economics, 59(1), 3-42.

Libman, A. (2013). Natural resources and sub-national economic performance: Does sub-national democracy matter? Energy Economics, 37, 82-99.

Mavrotas, G., Murshed, S. M., \& Torres, S. (2011). Natural resource dependence and economic performance in the 1970-2000 period. Review of Development Economics, 15(1), 124-138.

Mehlum, H., Moene, K., \& Torvik, R. (2006). Institutions and the resource curse. The Economic Journal, 116(508), 1-20.

Meltzer, A. H., \& Richard, S. F. (1981). A rational theory of the size of government. Journal of Political Economy, 89(5), 914-927.

Milanovic, B. (2016). Global inequality. Harvard University Press.

Muller, E. N. (1988). Democracy, economic development, and income inequality. American Sociological Review, 53(1), 50-68.

Nunez-Rocha, T., \& Turcu, C. (2019). Trade in Fuels and Environmental Regulation: A Two-Sided Story. Comparative Economic Studies, 61(2), 302-343.

Parcero, O. J., \& Papyrakis, E. (2016). Income inequality and the oil resource curse. Resource and Energy Economics, 45, 159-177.

Pastor, L., \& Veronesi, P. (2016). Income inequality and asset prices under redistributive taxation. Journal of Monetary Economics, 81, 1-20. 
Pomfret, R. (2011). Exploiting energy and mineral resources in Central Asia, Azerbaijan and Mongolia. Comparative Economic Studies, 53(1), 5-33.

Powell, J. \& Thyne, C. (2011). Global instances of coups from 1950 to 2010: A new dataset. Journal of Peace Research, 48(2), 249-259.

Piketty, T., Saez, E., \& Stantcheva, S. (2014). Optimal taxation of top labor incomes: A tale of three elasticities. American Economic Journal: Economic Policy, 6(1), 230-271.

Rånge, M., \& Sandberg, M. (2017). Political Institutions and Regimes since 1600: A New Historical Data Set. Journal of Interdisciplinary History, 47(4), 495-520.

Robinson, J. A., Torvik, R., \& Verdier, T. (2006). Political foundations of the resource curse. Journal of Development Economics, 79(2), 447-468.

Rodrik, D. (1999). Democracies pay higher wages. The Quarterly Journal of Economics, 114(3), 707-738.

Roine, J. \& Vlachos, J. \& Waldestrom, D. (2009). The long-run determinants of inequality: What can we learn from top income data? Journal of Public Economics, 93, 974-988.

Ross, M. L. (1999). The political economy of the resource curse. World Politics, 51(2), 297-322.

Ross, M. L. (2001). Does oil hinder democracy? World Politics, 53, 325-361.

Ross, M. L. (2006). Is democracy good for the poor? American Journal of Political Science, 50(4), 860-874.

Sachs, J. D., \& Warner, A. M. (2001). The curse of natural resources. European economic review, 45(4-6), 827-838. 
Saint Paul, G., \& Verdier, T. (1996). Inequality, redistribution and growth: A challenge to the conventional political economy approach. European Economic Review, 3(40), 719-728.

Sarmidi, T., Hook Law, S., \& Jafari, Y. (2014). Resource curse: New evidence on the role of institutions. International Economic Journal, 28(1), 191-206.

Scheidel, W. (2017). The Great Leveler: Violence and the History of Inequality from the Stone Age to the Twenty-First Century. Princeton University Press.

Smith, B. (2015). The resource curse exorcised: Evidence from a panel of countries. Journal of Development Economics, 116, 57-73.

Solt, F. (2016). The standardized world income inequality database. Social Science Quarterly, 97(5), 1267-1281.

Solt, F. (2015). On the assessment and use of cross-national income inequality datasets. Journal of Economic Inequality, 13, 683-691.

Soltow, L., \& van Zanden, J.L. (1998). Income and Wealth Inequality in the Netherlands, 16th-20th Century, Amsterdam: Het Spinhuis.

Spilimbergo, A., Londoño, J. L., \& Székely, M. (1999). Income distribution, factor endowments, and trade openness. Journal of Development Economics, 59(1), 77-101.

Timmons, J. F. (2010). Does democracy reduce economic inequality? British Journal of Political Science, $40(4), 741-757$. 
Tridico, P. (2018). The determinants of income inequality in OECD countries. Cambridge Journal of Economics, 42(4), 1009-1042.

Tsui, K.K. (2011). More oil, less democracy: Evidence from worldwide crude oil discoveries. Economic Journal, 121(551), 89-115.

Uslaner, E. (2009). The moral foundations of trust. Cambridge University Press: Cambridge, UK.

Van der Ploeg, F. (2011). Natural resources: curse or blessing? Journal of Economic Literature, 49(2), 366-420.

Van Bavel, B., \& Frankema, E. (2017). Wealth Inequality in the Netherlands, C. 1950-2015. The Paradox of a Northern European Welfare State. TSEG/ Low Countries Journal of Social and Economic History, 14(2), 29-62.

Wiig, A., \& Kolstad, I. (2012). If diversification is good, why don't countries diversify more? The political economy of diversification in resource-rich countries. Energy Policy, 40, 196-203. 


\section{APPENDIX}

\section{Table A.1 - Data definitions and sources}

\begin{tabular}{|l|l|}
\hline Income inequality & $\begin{array}{l}\text { Pre-tax income - Gini coefficient. Average 2010-2016. Solt (2016) - The } \\
\text { Standardized World Income Inequality Database }\end{array}$ \\
\hline Natural resource rents & $\begin{array}{l}\text { Total natural resource rents are the sum of oil rents, natural gas rents, } \\
\text { coal rents (hard and soft), mineral rents, and forest rents. Average 1980- } \\
\text { 2009. World Bank. }\end{array}$ \\
\hline $\begin{array}{l}\text { Democratic } \\
\text { accountability }\end{array}$ & $\begin{array}{l}\text { Responsiveness of government is to its citizens. International Country } \\
\text { Risk Guide (ICRG). 2009. }\end{array}$ \\
\hline Education expenditures & $\begin{array}{l}\text { The current operating expenditures in education, including wages and } \\
\text { salaries and excluding capital investments in buildings and equipment. } \\
\text { Average 1980-2009. World Bank. }\end{array}$ \\
\hline Life expectancy & Life expectancy at birth as of 1990. World Bank. \\
\hline Labor market regulations & $\begin{array}{l}\text { LAMRIG. Rigidity of employment protection legislation. Campos and } \\
\text { Nugent (2012). }\end{array}$ \\
\hline Technological progress & $\begin{array}{l}\text { The index of technological development from CHAT dataset. Comin and } \\
\text { Hobijn (2009). }\end{array}$ \\
\hline Net interest margin & $\begin{array}{l}\text { Accounting value of banks' net interest revenue as a share of average } \\
\text { interest-bearing assets. World Bank. }\end{array}$ \\
\hline GDP per capita & GDP level per capita in 1990. World Bank. \\
\hline Trust & Generalized trust. 2005-2009. World Values Survey Data. \\
\hline Revolutions and coups & $\begin{array}{l}\text { Revolutions and coups, total instances between 1950 and 2009. Powell } \\
\text { and Thyne (2011). }\end{array}$ \\
\hline
\end{tabular}

Table A.2 - Descriptive Statistics

\begin{tabular}{|l|c|c|c|c|c|}
\hline & Mean & Median & St. Dev. & Min & Max \\
\hline Income inequality & 44.11 & 44.04 & 7.13 & 26.89 & 66.09 \\
\hline Natural resource rents & 7.42 & 2.74 & 10.54 & 0 & 47.79 \\
\hline Democratic accountability & 0.65 & 0.66 & 0.25 & 0.05 & 1 \\
\hline Education expenditures & 4.04 & 3.86 & 1.97 & 0.99 & 15.14 \\
\hline Life expectancy & 64.77 & 68.3 & 10.06 & 34.21 & 78.83 \\
\hline Labor market regulations & 1.58 & 1.62 & 0.48 & 0.46 & 2.79 \\
\hline Technological progress & -0.01 & 0.14 & 0.79 & -1.69 & 1.29 \\
\hline Net interest margin & 5.11 & 4.76 & 2.83 & 0.66 & 12.81 \\
\hline GDP per capita & 8.61 & 8.68 & 1.2 & 6.23 & 11.6 \\
\hline Trust & 0.25 & 0.22 & 0.14 & 0.04 & 0.69 \\
\hline Revolutions and coups & 2.38 & 0 & 3.84 & 0 & 23 \\
\hline
\end{tabular}




\section{Countries included in the regressions:}

Albania, Algeria, Argentina, Armenia, Australia, Azerbaijan, Bangladesh, Belarus, Brazil, Bulgaria, Burkina Faso, Canada, Colombia, Croatia, Cyprus, Czech Republic, Dominican Republic, Ecuador, Egypt, Estonia, Ethiopia, Finland, France, Germany, Ghana, Guatemala, Hong Kong, Hungary, Chile, China, India, Indonesia, Iran, Israel, Italy, Japan, Jordan, Kazakhstan, Korea South, Latvia, Lebanon, Lithuania, Malaysia, Mali, Mexico, Moldova, Morocco, Netherlands, NewZealand, Nigeria, Norway, Pakistan, Peru, Philippines, Poland, Russia, Singapore, Slovakia, Slovenia, South Africa, Spain, Sweden, Switzerland, Tanzania, Thailand, Trinidad and Tobago, Tunisia, Turkey, Uganda, Ukraine, United Kingdom, United States, Uruguay, Venezuela, Vietnam, Yemen, Zambia, Zimbabwe. 